抗血小板剤の基礎と臨床

\title{
HDL の線溶系活性化作用についで
}

\author{
朔 啓二郎** 荒 川 規矩男** Masood AHMAD*** \\ Pia Glas-Greenwalt*** Moti L. KashyaP***
}

I. はじめに

血液線溶系の活性化は plasminogen (Pgen) が種 種の活性化因子, 生理的には tissue type plasminogen activator (TPA) 等により, plasmin (Pl) に 転換されて誘起される ${ }^{1)}$. この血液線溶系に血中 脂質がどのように関与するかについての報告は少
なく，過去の臨床データとして，高脂血症患者 （食餌性も含む）に線溶能低下を認めたという報告 がいくつかあるにすぎない2,3). 今回，われわれ は抗動脈硬化因子といわれる HDL に焦点をしぼ り，その血液線溶系に及ぼす影響を in vitro で検 討したので報告する.

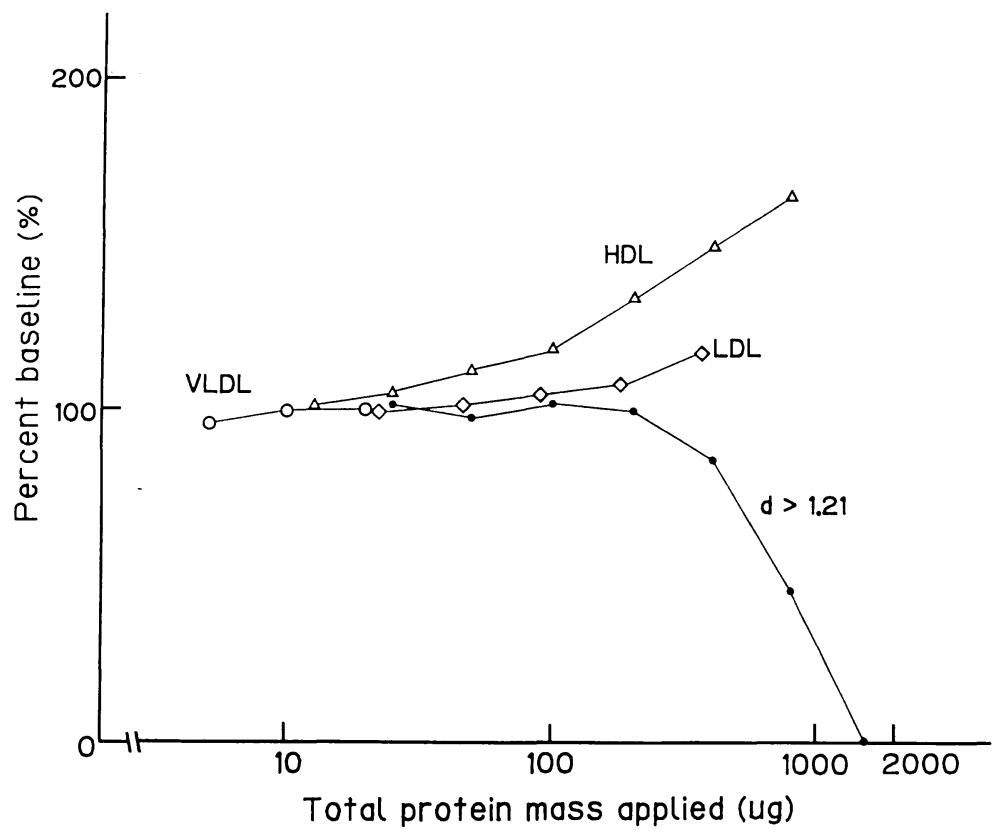

Fig. 1 Effects of addition of VLDL, LDL, HDL and lipoprotein deficient plasma (d> $1.21 \mathrm{~g} / \mathrm{m} l$ ) on fibrinolysis by fibrin plate method.

\footnotetext{
* 1986 年 1 月, 日本動脈硬化学会 昭和 60 年度冬季 大会に拉いて発表

** 福岡大学医学部第二内科

*** シンシナティ大学医学部内科
} 


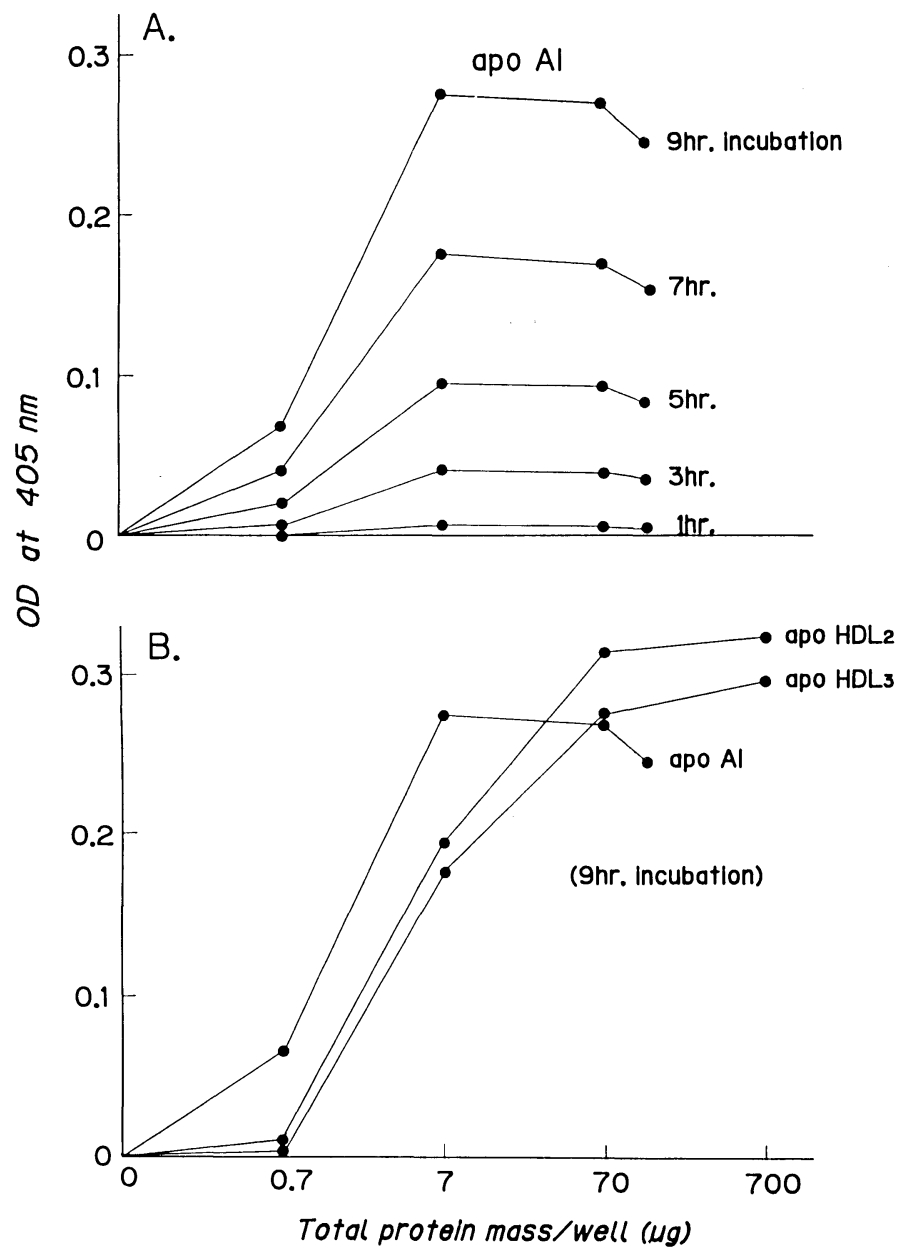

Fig. 2 A: Effect of addition of apo A-I on the time course of hydrolysis of S-2251 by urokinase activated plasminogen.

B: Effects of addition of apo A-I, apo $\mathrm{HDL}_{2}$ and apo $\mathrm{HDL}_{3}$ on hydrolysis of S2251 by urokinase activated plasminogen.

\section{II. 材料および方法}

\section{1. 試薬}

Fibrinogen (bovine plasminogen-free または plasminogen-rich) は Organon Teknika 社, bovine thrombin は Park Davis 社, urokinase は Abbott Lab, plasminogen は Sigma Chemical 社, S-2251 は Kabi Vitrum 社より購入した。

\section{2. リポ蛋白分離およびアポ蛋白精製}

健常女性 (45 歳) より 早朝空腹時採血し, 血漿 を分離した. VLDL, LDL, HDL, HDL $2, \mathrm{HDL}_{3}$ の各リポ蛋白分画は超遠心法により以前述べた
方法で分離し4), EDTA buffer (0.05 M sodium diethyl barbiturate, $0.1 \mathrm{M} \mathrm{NaCl}, 2.7 \mathrm{mM}$ EDTA, $\left.1.5 \mathrm{mM} \mathrm{NaN}_{3}, \mathrm{pH} 7.8\right)$ にて透析した. アポ蛋白 (apo) A-I は HDL 脱脂後, preparative isoelectric focusing を用い精製した ${ }^{4)}$.

\section{3. 線溶能 assay}

1) Fibrin plate 法5,6)

プラスティックシャーレ $(15 \times 100 \mathrm{~mm})$ に $6 \mathrm{~m} l$ $の$ bovine (plasminogen-rich) fibrinogen solution (最終濃度 $0.1 \%$ )を入れ, $0.2 \mathrm{ml}$ の bovine thrombin $(20 \mathrm{NIH}$ unit $/ \mathrm{m} l)$ を加え, fibrin plate を作製 した。検体 (リポ蛋白または control buffer, $80 \mu l$ ) 
は, urokinase (UK) (10 CAT units $/ \mathrm{ml}, 40 \mu l)$ と 混合後, $30 \mu l$ を plate に apply し, $37^{\circ} \mathrm{C}$ で 17 時 間 incubate 後の lysis area $\left(\mathrm{mm}^{2}\right)$ を测定した. Lysis area の大きさにより検体の plasminogen activation に及ぼす影響を観察した。

2) Chromogenic substrate (S-2251)を用いた assay 法?)

Plasmin および UK activated plasminogen に対 する chromogenic substrate S-2251 (H-D-ValLeu-Lys-pNA) $(3.5 \mathrm{mmol} / l, 70 \mu l)$, plasminogen (0.06 units $/ \mathrm{ml}, 200 \mu l$ ), UK (50 CAT unit $/ \mathrm{ml}$, $70 \mu l$ ) および検体（アポ蛋白または control buffer, $70 \mu l)$ を混合後, $37^{\circ} \mathrm{C}$ で incubate し, 遊離した pNA $405 \mathrm{~nm}$ で経時的に測定し, 検体の plasminogen activation に及ぼす影響を観察した。

\section{III. 結 果}

\section{Fibrin plate 法}

Control として bufferを用いた際の lysis area $\left(\mathrm{mm}^{2}\right)$ の平均を $100 \%$ とし, lysis area の変化を percent で表示した (Fig. 1). HDL の著明な線溶 活性化作用と $\mathrm{d}>1.21 \mathrm{~g} / \mathrm{m} l$ 分画の抑制作用を認 めた。

\section{S-2251 を用いた assay 法}

Figure 2A に示すごとく HDL の主蛋白 apo A-I の著明な線溶活性化作用を認めた。 Fig. 2B に apo A-I, apo HDL2, apo $\mathrm{HDL}_{3}$ の線溶能に及 ぼす作用の比較を示した。

\section{IV. 考 察}

線溶は血管内皮細胞由来の plasminogen activator により誘起される局所的反応であるが，apo
A-I が生体内でどのようなメカニズムで働きかけ ているかについては不明である。しかし，HDL の主蛋白である apo A-I が urokinase-plasminogen interaction を活性化する役割を演じていることは 上記実験より推察できる.Apo A-I の主な生理作 用である reverse cholesterol transport に加え，こ のような血栓症防止作用が in vivo でも実動して いるなら，HDL は動脈硬化症発症の防御因子と して二重の役割を果たしている可能性を示唆する ものである。

\section{文献}

1) Collen, D.: On the regulation and control of fibrinolysis. Thrombos. Haemostas., 43: 77-89 (1980).

2) O'Brien, J. R.: Blood coagulation before and after a fatty meal in patients with coronary-artery disease and in healthy controls. The Lancet, I: 410412 (1958).

3) Spottl, F., Holzknecht, F., and Braunsteiner, H.: Inhibitors of the plasminogen-activation in patients with primary "carbohydrate-induced" hypertriglyceridemia. J. Atheroscler. Res., 8: 821-826 (1968).

4) Saku, K., Gartside, P. S., Hynd, B. A. and Kashyap, M. L.: Mechanism of action of gemfibrozil on lipoprotein metabolism. J. Clin. Invest., 75: 1702-1712 (1985).

5) Haverkate, F. and Brakman, P. In: Progress in chemical fibrinolysis and thrombosis. J. F. Davidson, M. M. Samama, and P. C. Desnoyers (ed.), vol. 1, p. 151, Raven Press, New York (1975).

6) Glas-Greenwalt, P., Kant, K. S., Allen, C. and Pollak, V. E.: Fibrinolysis in health and disease: severe abnormalities in systemic lupus erythematosus. J. Lab. Clin. Med., 104: 962-976 (1984).

7) Takada, A., Urano, T. and Takada, Y.: Influence of coagulation on the activation of plasminogen by streptokinase and urokinase. Thrombos. Haemostas., 42: 901-908 (1979). 


\title{
Summary
}

\section{Apolipoproteins of Human High Density Lipoproteins Activate Fibrinolysis}

\author{
Keijiro SaKu*, Kikuo AraKawa*, Pia Glas-Greenwalt**, \\ Masood AHMAD** and Moti L. Kashyap** \\ *The Second Department of Internal Medicine, \\ Fukuoka University School of Medicine, Fukuoka 814-01, Japan \\ **Department of Internal Medicine, \\ University of Cincinnati Medical Center, Cincinnati, OH 45267 U.S.A.
}

The effects on fibrinolysis of purified normal human high density lipoproteins (HDL) and their apolipoproteins (apo) were assessed in an in vitro system containing urokinase, plasminogen and fibrin. HDL significantly increased lysis area of plated fibrin compared to controls. The hydrolysis of a chromogenic substrate (S-2251: H-D-Val-LeuLys-pNA) specific to plasmin or urokinase activated plasminogen was higher in the presence of apo A-I, apo $\mathrm{HDL}_{2}$, and apo $\mathrm{HDL}_{3}$. These data suggest that the major protein of HDL-apo A-Iand possibly certain minor apo constituent(s) of HDL may participate in the fibrinolytic process and propose a new function for HDL.

Key words: Fibrinolysis, Urokinase, Plasminogen, Chromogenic substrate (S-2251), High density lipoproteins, Apolipoprotein A-I. 